\title{
Clinical outcomes of laparoscopic treatment of non-palpable testis in children at a tertiary pediatric surgery center
}

\author{
Üçüncü basamak bir çocuk cerrahisi merkezinde çocuklarda palpe edilemeyen testislerin \\ laparoskopik tedavisinin klinik sonuçları
}

Seref Selcuk Kilic ${ }^{*}$, Onder Ozden ${ }^{1}$, Selcan Turkan Colak $^{1}$, Kamuran Tutus ${ }^{1}$, Murat Alkan ${ }^{1}$, Recep Tuncer ${ }^{1}$

1. Cukurova University Faculty of Medicine, Department of Pediatric Surgery, Adana, Turkey

\begin{abstract}
Aim: Non-palpable testis is defined as the absence of the testis in the inguinal canal and scrotum in a male patient. It is important to define the condition and location of the non-palpable testis, to prevent the risks of infertility and malignant transformation of the testis in patients. We aimed to evaluate the results of the laparoscopic approach we applied in the treatment of pediatric patients with non-palpable testes.

Methods: Patients with non-palpable testes, diagnosed and treated by the laparoscopic approach in a tertiary pediatric surgery center, were evaluated retrospectively. In the treatment protocol, laparoscopic abdominal exploration, twostage Fowler-Stephens laparoscopic orchiopexy, primary laparoscopic orchiopexy and inguinal exploration surgical approaches were applied according to the case characteristics

Results: Data from 54 testes in 45 pediatric patients were evaluated. Intra-abdominal testis was detected in $46.2 \%$ of the cases, with $88 \%$ of them at the entrance of the internal inguinal ring. After laparoscopic abdominal exploration, two-stage FowlerStephens in $7(28 \%)$, primary laparoscopic orchiopexy in $18(72 \%)$ were applied of testes. Inguinal exploration was performed in $27(50 \%)$ whom no testis could not found. Seventeen $(73.9 \%)$ of 23 testes that were descended into the scrotum remained viable, while atrophy occurred in $6(26 \%)$ of them. Viable testis cells were not detected in the histopathology of 27 excised nubbins.

Conclusions: The laparoscopic approach is a reliable and effective method in the diagnosis and treatment of non-palpable testis. Localization of intra-abdominal testes may support consideration of the inguinal exploration approach as the primary surgical intervention.
\end{abstract}

Keywords: Testis; undescended testis; laparoscopy; orchiopexy; pediatrics

\section{Öz}

Amaç: Palpe edilemeyen testis, erkek bir hastada testisin inguinal kanal ve skrotum içerisinde bulunmaması şeklinde tanımlanır. Hastada infertilite ve testiste malign transformasyon gelişim riskini engellemek için palpe edilemeyen testisin yerleşimi ve durumunun tanımlanması önemlidir. Amacımız, palpe edilemeyen testis tanılı çocuk hastalarda tedavide uyguladığımız laparoskopik yaklaşımın sonuçların değerlendirmekti.

Yöntemler: Üçüncü basamak bir çocuk cerrahisi merkezinde palpe edilemeyen testis tanısı konulmuş ve laparoskopik yaklaşım ile tedavi edilmiş hastalar geriye dönük olarak incelendi. Hastaların özelliklerine göre tedavi protokolünde, laparoskopik abdominal eksplorasyon, iki aşamalı Fowler-Stephens laparoskopik orşiopeksi, primer laparoskopik orşiopeksi ve inguinal eksplorasyon uygulandı.

Bulgular: Kırk beş çocuk hastadaki 54 testise ait veriler incelendi. Vakaların $\% 46.2$ 'sinde intra abdominal yerleşimli saptanan testislerin \%88'i internal inguinal ring girişinde yerleşimliydi. Laparoskopik abdominal eksplorasyondan sonra testislerin 7 (\%28)'sine iki aşamalı Fowler-Stephens, 18 (\%72)'ine primer laparoskopik orşiopeksi uygulandı. Testis bulunamayan $27(\% 50)$ vakaya inguinal eksplorasyon uygulandı. Skrotuma indirilen 23 testisin 17 (\%73.9)'si normal iken, 6 (\%26)'sında atrofi gelişti. Eksize edilen 27 inguinal nubbinde testis ait canlı hücreler saptanmadı.

Sonuçlar: Palpe edilemeyen testisin tanı konulması ve tedavisinde laparaskopi güvenilir ve etkili bir yöntemdir. Abdomen içi testislerin yerleşim yeri, öncelikli cerrahi yaklaşım olarak inguinal eksplorasyonun düşünülmesini destekleyebilir.

Anahtar Kelimeler: Testis; inmemiş testis; laparoskopi; orşiopeksi; pediatri

Received: 29.06.2021 Accepted: 25.09.2021 Published (Online):31.12.2021

*Corresponding Author: Seref Selcuk Kilic, Cukurova University Faculty of Medicine Department of Pediatric Surgery, Adana, Turkey.+905415423168, serefselcukkilic@gmail.com

ORCID: 0000-0002-3589-3473

To cited: Kilic SS, Ozden O, Colak ST, Tutus K, Alkan M, Tuncer R. Clinical outcomes of laparoscopic treatment of non-palpable testis in children at a tertiary pediatric surgery center. Acta Med Alanya 2021;5(3):294-300

doi: $10.30565 /$ medalanya. 959384 


\section{INTRODUCTION}

N on-palpable testis (NPT) is the absence of the testis in the scrotum and inguinal canal. Cases of non-palpable testis constitute 20-30\% of the undescended testis cases [1]. Because of the low fertility in patients with undescended testis and the increased incidence of carcinoma in situ in the affected testes, it is important to determine the location and developmental status of a nonpalpable testis [2, 3].

Physical examination and radiological imaging methods are used to locate a NPT in the inguinal and scrotal regions. However, the American Urology Association (AUA) has emphasized that the location of the testis cannot be detected $100 \%$ through pre-operative imaging methods. AUA does not recommend ultrasound examination because the sensitivity and specificity of ultrasound about NPT detection, which is the most frequently performed examination, is low (45 and $78 \%$ respectively) [4]. Patients with bilateral NPT should be evaluated for Disorder of Sex Development (DSD) [5].

Although there are different options such as laparoscopic exploration of the abdomen or inguinal exploration to determine the location of the testis in patients with non-palpable testis, it is a common and accepted practice to start with a laparoscopic exploration [6, 7]. In patients without an intra-abdominal testis, atrophied testicular tissue (nubbin) may be present in the inguinal canal or scrotum. Germ cells have been identified in the histopathology of $0-16 \%$ of inguinal/scrotal nubbins, and routine excision of the nubbin is a controversial issue [8].

The treatment goal for an abdominally-located testis is to bring it into the scrotum in a viable and tension-free condition. Primary orchiopexy and one- or two-stage Fowler-Stephens surgeries are the main surgical methods to achieve this aim [4]. These surgical approaches can be performed through open surgery or laparoscopic methods.

In our study, it was aimed to evaluate the results of the laparoscopic approach we applied in the treatment of pediatric patients with NPT.

\section{METHODS}

Between January 2007 and January 2020, a diagnosis of NPT was made in our clinic, the laparoscopic method was used in the treatment, and pediatric patients under 18 years were investigated. The study was approved by the Çukurova University Faculty of Medicine Ethics Committee (Meeting no: 109, Decision no: 4). The medical records of the patients regarding diagnosis, treatment and follow-up were evaluated retrospectively. Informed consent was obtained from the families of the patients involved in the study. Patients who did not have a palpable testis in the inguinal and scrotal region on physical examination were accepted with a diagnosis of a non-palpable testis. For these patients, ultrasound was performed to detect the presence of gonad in their inguinal and scrotal regions.

In the surgical approach in patients with nonpalpable testis, the presence of normal or atrophic testicular tissue was checked by examining the inguinal canal and scrotum after induction of general anesthesia. Laparoscopic exploration was initiated when there was no structure compatible with the testis. The abdomen was entered into from the umbilicus with an open method with a $5 \mathrm{~mm}$ trocar. Pneumoperitoneum was created with $\mathrm{CO} 2$ gas at a pressure of $10-12 \mathrm{mmHg}$. Testis, ductus deferens, vessels and structures entering the inguinal canal were evaluated. If such evaluation with the camera view was not sufficient, a $5 \mathrm{~mm}$ trocar was placed just below the umbilicus level, just lateral to the rectus muscle on the right or left, using the open method. In case it was decided to perform primary laparoscopic orchiopexy or Fowler-Stephens surgery, the second $5 \mathrm{~mm}$ trocar was placed symmetrical to the first trocar. After the intra-abdominal testis was released, the ductus deferens and vessels were preserved, and the testis was made to descend into the scrotum by creating a new pathway through the inguinal canal. The testis was fixed by trying to make it descend into the scrotum without tension. Twostage Fowler-Stephens surgery was performed in patients with short intra-abdominal testicular vessels and where it was considered that the testis could not be made to descend into the scrotum.

In the first stage of Fowler-Stephens, the 
connection between the testis and the testicular vessels is separated and blood supply of the testis is provided from the collaterals. At least 6 months after the first session, the testis, which was planned to descend, was released while maintaining the peripheral blood flow. Inguinal exploration was performed in cases where intraabdominal testis was not detected through laparoscopic exploration. Atrophic tissues that could be testis in the inguinal canal or scrotum were excised. Treatment success was defined as the testis being into the scrotum and being alive in the scrotum at follow-up.

Statistical analysis: IBM SPSS Statistics Version 20.0 program was used for data analysis. Age at diagnosis, age at surgery and duration of followup were defined as the median value (minimummaximum), and other quantitative data as percentages.

\section{RESULTS}

The data of 54 non-palpable testes in 45 patients who met the research criteria were analyzed. The demographic characteristics and comorbidities of the patients with a median age of diagnosis of 12 (2-144) months are shown in Table 1.

Table 1: Characteristics of Study Group

\begin{tabular}{|l|l|}
\hline Age of diagnosis (month) $(\mathrm{n}=45)$ & $12(2-144)$ \\
\hline Age of surgery (month) $(\mathrm{n}=45)$ & $24(6-156)$ \\
\hline Concomitant diseases $\mathrm{n}(\%)(\mathrm{n}=45)$ & $12(26.6)$ \\
\hline Patent ductus arteriosus & 2 \\
\hline Meningomyelosel & 1 \\
\hline Hepatoblastoma & 1 \\
\hline Russel Silver syndrome & 1 \\
\hline Prune Belly syndrome & 1 \\
\hline Posterior uretral valve & 1 \\
\hline Tricuspit stenosis & 1 \\
\hline Prader Willi syndrome & 1 \\
\hline Malign mesenchimal tumor & 1 \\
\hline Aort stenosis & 1 \\
\hline VACTERL & 1 \\
\hline Side (n=45) & \multicolumn{2}{|l|}{} \\
\hline Right & $13(28,8)$ \\
\hline Left & $23(51.1)$ \\
\hline Bilateral & $9(20)$ \\
\hline Follow-up (PLO+ FS2) (month) $(\mathrm{n}=17$ testes) & $12(4-130)$ \\
\hline
\end{tabular}

Data are given as number of cases $(n)$, percentage (\%) and median (minimum-maximum), PLO: Primary laparoscopic orchiopexy, FS2: Fowler-Stephens stage 2
During the diagnosis, physical examination and ultrasound findings of the scrotal and inguinal regions were used. Nine patients with bilateral NPT were evaluated by the pediatric endocrinology department, with karyotype analysis and human Chorionic Gonadotrophin (hCG) stimulation test performed. The karyotype of these 9 patients was determined as $46 \mathrm{XY}$, and 8 patients had a testosterone response to hormone stimulation. Laparoscopic abdominal exploration was performed for all the patients as the primary surgical method. The treatment management of patients with non-palpable testis is presented in Figure 1. Inguinal exploration was performed in one of three patients whose intra-abdominal testis was not detected in the laparoscopic exploration, whose testicular artery was not developed, and who ended up blind. Laparoscopic exploration findings and data about histopathology and complications are depicted in Table 2. As a result of the treatment, $23(92 \%)$ of 25 intra-abdominal testes found in NPT patients descended to the scrotum. In their follow-up, 17 (73.9\%) of these 23 testes were viable. After primary laparoscopic orchiopexy, a $30 \%$ reduction in testis size was detected in one patient, the blood supply to which was found to be normal in the follow-up. The outcomes of surgical procedures presented in Table 3.

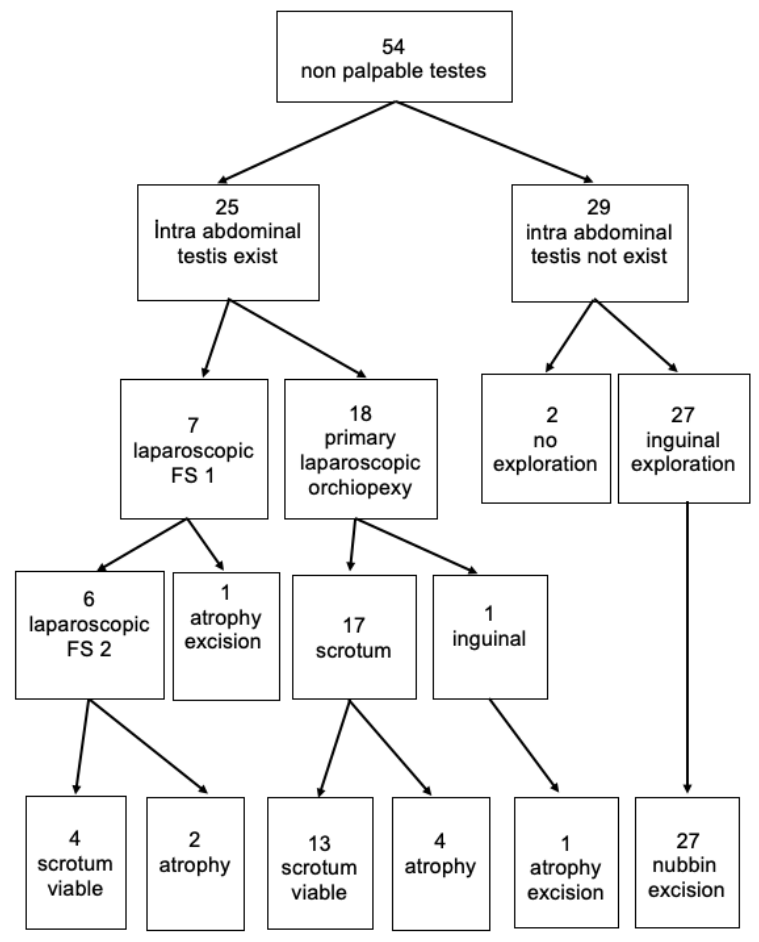

Figure 1. Treatment management of patients 
Table 2: Data of The Laparoscopic Exploration, Histopathology and Complication

\begin{tabular}{|l|l|l|}
\hline & $\mathrm{n}$ & $\%$ \\
\hline Intra-abdominal testis & 54 & \\
-Yes & 25 & 46.2 \\
-Non & 29 & 53.8 \\
\hline Localization of intra-abdominal testis & 25 & \\
-Not at the entrance of the internal inguinal ring & 3 & 12 \\
-At the entrance of the internal inguinal ring & 22 & 88 \\
\hline Appearance of testicular artery in the abdomen & 29 & \\
(Intraabdominal testis (-) group) & & \\
-Normal & 17 & 58.6 \\
-Atrophic & 9 & 31 \\
-Blind ending & 3 & 10.3 \\
\hline Histopathology (nubbin) & 27 & \\
-Testis tissue & 0 & 0 \\
-Ductus Deferens & 16 & 59.2 \\
-Calcified and fibrous tissue & 11 & 40.8 \\
\hline Complication & $25^{*}$ & 32 \\
-Testis atrophy & 8 & \\
\hline
\end{tabular}

Data are given as number of cases $(\mathrm{n})$ and percentage (\%). *: Patients with intra-abdominal testis detected

Table 3: Successful rate of surgical interventions

\begin{tabular}{|l|l|l|}
\hline & $\mathrm{n}$ & Success n (\%) \\
\hline Primary laparoscopic orchiopexy & 18 & $13(72.2)$ \\
\hline $\begin{array}{l}\text { Two-stage Fowler-Stephens laparoscopic } \\
\text { orchiopexy }\end{array}$ & 7 & $4(57.1)$ \\
\hline $\begin{array}{l}\text { Testis that final position is in the scrotum and } \\
\text { viable } \\
\text { (testis that orchiopexy performed) }\end{array}$ & 23 & $17(73.9)$ \\
\cline { 2 - 4 }
\end{tabular}

Data are given as number of cases (n) and percentage (\%).

\section{DISCUSSION}

Our study aimed to evaluate the results of the laparoscopic approach in the treatment of patients with NPT. According to our clinical results, the success of the FS approach and primary laparoscopic orchiopexy seems low, compared to the literature. In our study group, the location of the testes in the abdomen was mostly close to the entrance of the internal inguinal canal, suggesting that it may be appropriate to start the surgery with inguinal exploration first.

The median age of diagnosis of the patients was $12(2-144)$ months, and the median age of surgery 24 (6-156) months. Although the median age at diagnosis was consistent with previous publications, the median age at surgery was found to be higher $[9,10]$. Of the patients, $51.1 \%$ had NPT on the left side, $28.8 \%$ on the right, and
$20 \%$ had bilateral NPT. Detection of non-palpable testis mostly on the left and the frequency of bilateral NPT were consistent with the literature $[9,10,11,12]$.

Tasian et al. reported that the sensitivity of ultrasound in showing the testis in NPT patients was $45 \%$, that it could not reliably localize the testis and could not exclude the presence of intra-abdominal testis [4]. The American Urology Association does not recommend the use of diagnostic radiological imaging in patients with NPT, due to the low reliability of ultrasound, the danger of ionizing radiation in computed tomography, the need for anesthesia in children during magnetic resonance imaging (MRI), and the cost of MRI [5]. The European Association of Urology / European Society for Paediatric Urology (EAU/ESPU) considers it appropriate to use methods such as ultrasound and MRI only in cases of suspected DSD and in special cases where it is important to measure palpable testis size [13]. All patients in our study group were evaluated by ultrasound. No testis or nubbin tissue could be demonstrated in the inguinal region and scrotum on the non-palpable side of the testis in any patient.

As stated in the guidelines of AUA and ESPU, karyotype research and hCG stimulation test were performed to evaluate the risk of DSD in patients with bilateral NPT $[5,13]$. There was no testosterone response to the hCG stimulation test in a patient with bilateral NPT who did not have an intra-abdominal testis and had a karyotype of $46 \mathrm{XY}$. In the inguinal exploration of this patient, no tissue compatible with the testis was observed on the left, while the removal of $5 \mathrm{~mm}$ tissue with streak gonad appearance on the right was not accepted by the family. There was a testosterone response to the hCG hormone in other patients with bilateral NPT. In patients with non-palpable testis, if the testis is not palpable in the physical examination performed under anesthesia, abdominal exploration with a laparoscopic approach is widely accepted to evaluate the presence of intra-abdominal testis [6]. In all our patients, laparoscopic abdominal exploration was performed first when the testis was not palpable under anesthesia. Intra-abdominal testis frequency in NPT patients has been defined as 40- 
$61 \%$ in some studies $[9,12,14,15]$. In our study, 25 $(46.2 \%)$ of the 54 NPTs were found to have testis in the abdomen. When the locations of 25 intraabdominal testes were evaluated, 22 (88\%) were found to be at the entrance of the internal inguinal ring. There are different opinions about starting the primary surgical approach with inguinal/ scrotal exploration or laparoscopic exploration of the abdomen in NPTs [7]. Igarashi et al. reported that the testis was found and descended into the scrotum by inguinal exploration in $39 \%$ of 72 patients with NPT in the operations they started with inguinal exploration, and they recommended that laparoscopy be done after the inguinal approach [9]. Callewaert et al. reported that the testes could be made to descend into the scrotum with the high scrotal Bianchi incision in $78 \%$ of 46 NPTs [7]. The fact that the intra-abdominal testes in our study were close to the internal inguinal ring entrance in a large proportion of $88 \%$, evaluated together with the literature, makes it reasonable to re-question the place of laparoscopy in the primary surgical approach.

The term 'high testis' defines a testis that cannot be made to descend into the scrotum without tension, due to the shortness of the ductus deferens and testicular artery [16]. Methods such as the Shehata technique, gradual orchiopexy by preserving the spermatic vessels, autotransplantation, and the application of the 1- or 2-stage FS technique have been described for these testes [17,18,19,20,21]. $A U A$ and EAU/ESPU recommend 1- or 2-stage FS orchiopexy for the treatment of high intraabdominal testis $[13,19]$. It has been reported in different publications that the two-stage approach has better success rates than the single-stage approach $(85 \%, 80 \%$, respectively) $[16,19]$. Esposito et al. revealed a success rate of $83.3 \%$ in 12 patients who were followed up for more than 10 years with two-stage FS and found a loss of size in the testes which descended into the scrotum, compared to the normal testis on the opposite side [22].

Primary orchiopexy could not be performed in $7(28 \%)$ of the 25 intra-abdominal testes due to testicular artery shortness, and these patients underwent FS surgery spread over 2 sessions. Post-first stage atrophy developed in one of the 7 testes in which two-stage FS was applied and this testis was excised laparoscopically. The remaining 6 testes were reduced to the scrotum with FS 2 stage surgery. In the follow-up of these testes, testicular atrophy developed in 2 patients. The development of the remaining 4 testes was normal. Our success rate in the two-stage FS approach is $57.1 \%$, which is below the literature. This may be due to the low number of patients and the failure to preserve the blood supply to the testis during FS 2, the insufficient blood supply to the testis after FS 1, or making the testis descend tensely into the scrotum, which may disrupt the blood supply.

Primary laparoscopic orchiopexy was applied to $18(72 \%)$ of the 25 intra-abdominal testes in the study group. While 17 testes descended into the scrotum with the help of laparoscopy, one testis was fixed in the middle of the inguinal canal, where it could be brought distally. However, during the follow-up, atrophy developed in this testis and it was excised. Thirteen (72.2\%) of the 18 testes that underwent primary laparoscopic orchiopexy were viable in the scrotum. This success rate can be termed low compared to $96.4 \%$ in the literature [23]. Of the 23 testes (6 FS 2nd session, 17 primary laparoscopic orchiopexy) that descended into the scrotum, $17(73.9 \%)$ were found to be in the scrotum and were found viable by doppler ultrasound examination. In 6 of the 23 testes, reduction in testis size was detected in the first 3 months post-operatively, and their size decreased below $0,5 \mathrm{~cm}$ in the follow-up. One of these three atrophic testes was excised.

An important evaluation step in patients without testis in intra-abdominal exploration is the evaluation of the testicular artery. The AUA and EAU/ESPU guidelines recommend inguinal exploration if the testicular vessels appear to have entered the inguinal canal, while further processing is not recommended in the presence of a vessel with a blind-ending [15, 19]. However, Sturm et al. reported that inguinal/scrotal nubbin was present in $72 \%$ of 36 cases whose testicular vessels ended blindly in laparoscopic exploration [15].

Excision of nubbin tissue, if present, is the approach generally used in inguinal or scrotal exploration. The necessity of removing the nubbin, which is 
thought to be atrophic testicular tissue, is due to the concern that malignant transformation may occur in the tissue [24]. Natajara et al. reported that viable germ cells and seminiferous tubules are found in 1 in 10 and 1 in 20 , respectively, in inguinal/scrotal nubbins [8]. Some researchers differ and argue that the risk of malignancy development from nubbin tissues is very low and that the defined samples are not strong, thus finding is no strong evidence for routine nubbin excision $[8,25]$. In our study, it was observed that the testicular vessels ended blindly before entering the inguinal canal in 3 of the cases where no intra-abdominal testis was detected. Inguinal exploration was performed in one of these 3 cases and $4 \mathrm{~mm}$ of nubbin tissue was excised. Histopathological examination of this tissue has been reported as ductus deferens and epididymis. Inguinal exploration was not performed for the other two testes. Histopathological examination of 27 nubbin tissues, which were excised, was reported as ductus deferens in $16(59.2 \%)$ and calcified and fibrous tissue in $11(40.8 \%)$; viable testis structures were not detected in these tissues.

The most common complication in the study group was atrophy of $8(32 \%)$ of the 25 testes with intraabdominal presence during the treatment process. Testis ascent and surgical site infection were not detected in any of the patients. The followup period of 17 testes that descended into the scrotum after orchiopexy was 12 (4-130) months. After weekly, monthly, 3-month, and 6-month follow-ups after orchiopexy, annual physical examination and testis dimensions were followed by scrotal ultrasound.

There are some important limitations in our study. The limited number of patients participating in the study makes it difficult to properly evaluate the results of an infrequent surgical method such as FS. A standard and homogeneous approach in the treatment of NPT may not have been developed due to the study not being designed prospectively, the cases being performed by different surgeons, and the effects of inexperienced surgeons receiving training.

\section{CONCLUSIONS}

The laparoscopic approach is a reliable and effective method in the diagnosis and treatment of non-palpable testis. Our study showed inguinal exploration as a suitable alternative to laparoscopic exploration for primary surgical intervention, to detect the presence of testis in NPT and treatment, since intra-abdominal testes were most likely detected at the entrance of the inguinal canal. Further research is essential to reveal the causes of testicular atrophy after orchiopexy.

Conflict of Interest: The author declares no conflict of interest related to this article.

Funding sources: The author declares that this study has received no financial support

Ethics Committee Approval: Ethical evaluation of the study was made and approved by Çukurova University Faculty of Medicine Noninterventional Clinical Research Ethics Committee (05.03.2021/109-4).

Peer-review: Externally and internally peer reviewed.

\section{REFERENCES}

Smolko MJ, Kaplan GW, Brock WA. Location and fate of the nonpalpable testis in children. J Urol. 1983;129(6):1204-6. DOI: 10.1016/s0022-5347(17)52643-9.

2. Tasian GE, Hittelman AB, Kim GE, DiSandro MJ, Baskin LS. Age at orchiopexy and testis palpability predict germ and Leydig cell loss: clinical predictors of adverse histological features of cryptorchidism. J Urol. 2009;182(2):704-9. DOI: 10.1016/j. juro.2009.04.032

3. Giwercman A, Bruun E, Frimodt-Møller C, Skakkebaek NE. Prevalence of carcino$\mathrm{ma}$ in situ and other histopathological abnormalities in testes of men with a history of cryptorchidism. J Urol. 1989;142(4):998-1001: discussion 1001-2. DOI: 10.1016/ s0022-5347(17)38967-X

4. Tasian GE, Copp HL. Diagnostic performance of ultrasound in nonpalpable cryptorchidism: a systematic review and meta-analysis. Pediatrics. 2011:127(1):119-28. orchidism: a systematic review

5. Kolon TF, Herndon CD, Baker LA, Baskin LS, Baxter CG, Cheng EY, et.al. American Urological Assocation. Evaluation and treatment of cryptorchidism: AUA guideline. J Urol. 2014;192(2):337-45. DOI: 10.1016/j.juro.2014.05.005.

6. Mah LW, Durbin-Johnson B, Kurzrock EA. Non-palpable testis: is management consistent and objective? J Pediatr Urol. 2020;16(1):62-8. DOI: 10.1016/j.jpurol.2019.11.015.

7. Callewaert PR, Rahnama'i MS, Biallosterski BT, van Kerrebroeck PE. Scrotal approach to both palpable and impalpable undescended testes: should it become our first choice? Urology. 2010;76(1):73-6. DOI: 10.1016/j.urology.2009.09.096.

8. Nataraja RM, Yeap E, Healy CJ, Nandhra IS, Murphy FL, Hutson JM, et al. Presence of viable germ cells in testicular regression syndrome remnants: Is routine excision indicated? A systematic review. Pediatr Surg Int. 2018;34(3):353-61. DOI: 10.1007/ s00383-017-4206-0.

9. Igarashi A, Kikuchi K, Ogushi K, Hasegawa M, Hatanaka M, Fujino J, et al. Surgical exploration for impalpable testis: Which should be first, inguinal exploration or laparoscopic abdominal exploration? J Pediatr Surg. 2018;53(9):1766-9. DOI: 10.1016/j.jpedsurg.2017.10.046.

10. Hamidi N, Telli O, Bagci U, Esen B, Karagoz MA, Hascicek AM, et al. Outcomes of Laparoscopic Treatment Modalities for Unilateral Non-palpable Testes. Front Pediatr. 2016;4:13. DOI: 10.3389/fped.2016.00013.

11. Geuvbashian G, Jednak R, Capolicchio JP, El-Sherbiny M. Outcome of surgical management of non-palpable testes. Urol Ann. 2013;5(4):273-6. DOI: 10.4103/0974-7796.120306.

12. Denes FT, Saito FJ, Silva FA, Giron AM, Machado M, Srougi M. Laparoscopic diagnosis and treatment of nonpalpable testis. Int Braz J Urol. 2008;34(3):329-34; discussion 335. DOI: 10.1590/s1677-55382008000300010.

13. Radmayr C, Dogan HS, Hoebeke P, Kocvara R, Nijman R, Silay S, et al. Management of undescended testes: European Association of Urology/European Society for Paediatric Urology Guidelines. J Pediatr Urol. 2016;12(6):335-43. DOI: 10.1016/j.jpurol.2016.07.014

14. Marret JB, Ravasse P, Boullier M, Blouet M, Dolet N, Petit T, et al. Surgery for no 
palpable testis before the age of one year: a risk for the testis? J Pediatr Urol. 2019;15(4):377.e1-377.e6. DOI: 10.1016/j.jpurol.2019.03.019.

15. Sturm R, Kurzrock E, Amend G, Shannon R, Gong E, Cheng E. Blind ending vessels on diagnostic laparoscopy for nonpalpable testis: Is a nubbin present? J Pediatr Urol. 2017;13(4):392.e1-392.e6. DOI: 10.1016/j.jpurol.2017.04.010.

16. Elyas R, Guerra LA, Pike J, DeCarli C, Betolli M, Bass J, et al. Is staging beneficial for Fowler-Stephens orchiopexy? A systematic review. J Urol. 2010;183(5):2012-8. DOI: 10.1016/j.juro.2010.01.035.

17. Shehata S, Shalaby R, Ismail M, Abouheba M, Elrouby A. Staged laparoscopic traction-orchiopexy for intraabdominal testis (Shehata technique): Stretching the limits for preservation of testicular vasculature. J Pediatr Surg. 2016;51(2):211-5. DOI: 10.1016/j.jpedsurg.2015.10.063.

18. Dessanti A, Falchetti D, lannuccelli M, Milianti S, Altana C, Tanca AR, et al. Cryptorchidism with short spermatic vessels: staged orchiopexy preserving spermatic vessels. J Urol. 2009;182(3):1163-7. DOI: 10.1016/j.juro.2009.05.050.

19. Tackett LD, Wacksman J, Billmire D, Sheldon CA, Minevich E. The high intra-abdominal testis: technique and long-term success of laparoscopic testicular autotransplantation. J Endourol. 2002;16(6):359-61. DOI: 10.1089/089277902760261383.

20. Fowler R, Stephens FD. The role of testicular vascular anatomy in the salvage of high undescended testes. Aust N Z J Surg. 1959;29:92-106. DOI: 10.1111/j.14452197.1959.tb03826.x.

21. Ransley, PG, Vordermark JS, Caldamone AA, Bellinger MF. Preliminary ligation of the gonadal vessels prior to orchidopexy for the intra-abdominal testicle. World $J$ Urol 1984;2:266-8. DOI: 10.1007/BF00326700.

22. Esposito C, Vallone G, Savanelli A, Settimi A. Long-term outcome of laparoscopic Fowler-Stephens orchiopexy in boys with intra-abdominal testis. J Urol. 2009;181(4):1851-6. DOI: 10.1016/j.juro.2008.12.003.

23. Kim J, Min GE, Kim KS. Laparoscopic orchiopexy for a nonpalpable testis. Korean J Urol. 2010;51(2):106-10. DOI: 10.4111/kju.2010.51.2.106.

24. Rozanski TA, Wojno KJ, Bloom DA. The remnant orchiectomy. J Urol. 1996;155(2):712-3; discussion 714. DOI: 10.1016/S0022-5347(01)66507-8.

25. Woodford E, Eliezer D, Deshpande A, Kumar R. Is excision of testicular nubbin necessary in vanishing testis syndrome? J Pediatr Surg. 2018;53(12):2495-7. DOI: 10.1016/j.jpedsurg.2018.08.011

\begin{tabular}{|l|l|}
\hline Author / ORCID & Authorship Contrubition \\
\hline $\begin{array}{l}\text { Seref Selcuk Kilic } \\
\text { 0000-0002-3589-3473 }\end{array}$ & $\begin{array}{l}\text { Consept, Design, Materials, Data } \\
\text { Collection and Processing, Literature } \\
\text { review, Analysis, Manuscript writing, }\end{array}$ \\
\hline $\begin{array}{l}\text { Onder Ozden } \\
\text { 0000-0001-5683-204X }\end{array}$ & Critical Review, Data Collection, Analysis \\
\hline $\begin{array}{l}\text { Selcan Turkan Colak } \\
0000-0003-4481-0163\end{array}$ & Literature review Critical review \\
\hline $\begin{array}{l}\text { Kamuran Tutus } \\
0000-0003-2469-9963\end{array}$ & Literature review Critical review \\
\hline $\begin{array}{l}\text { Murat Alkan } \\
0000-0001-5558-9404\end{array}$ & Critical review Fianl Approval \\
\hline $\begin{array}{l}\text { Recep Tuncer } \\
0000-0003-4670-8461\end{array}$ & Consept, Critical review Critical review \\
\hline
\end{tabular}

